\title{
A promising therapy of tocilizumab and helmet CPAP to prevent intubation for COVID-19 induced severe ARDS: a case report
}

\author{
Septian Adi Permana ${ }^{1 *}$, Adhrie Sugiarto ${ }^{1}$, Muhammad Husni Thamrin ${ }^{2}$, Arifin ${ }^{2}$, Harsini ${ }^{3}$ \\ Author affiliations: \\ 1- Anesthesiology \& Intensive Care Department, University Indonesia, Jakarta, Indonesia \\ 2- Intensive Care Department, Dr Moewardi General Hospital, Surakarta, Indonesia \\ 3- Pulmonology Department, Dr Moewardi General Hospital, Surakarta, Indonesia \\ *Correspondence: Septian Adi Permana; E-mail: septian.adi03@gmail.com
}

\section{Abstract}

A 59 yrs old male with severe ARDS due to COVID-19 infection was in life threatening 'cytokine storm'. He had also co-morbids including diabetes mellitus and hypertension. He had come from Grobogan, a red area for COVID-19. Clinical finding indicted systemic inflammatory response syndrome (SIRS) with dyspnea, tachycardia, and high fever.

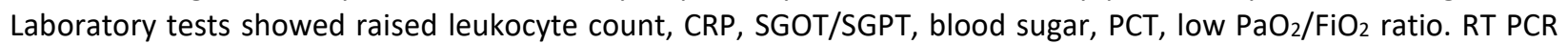
showed he was infected by COVID-19. Sputum culture showed Klebsiella infection and CXR showed bilateral pneumonia.

Patient was treated with standard therapy and a combination of tocilizumab for cytokine-storm and helmet CPAP for severe ARDS.

Helmet CPAP has become the first modality for COVID-19 ARDS in some countries but not in Indonesia. We chose helmet CPAP because of the cost efficient, comfortable, and easy operation compared to other modality. We chose tocilizumab because it uses a single dose. Although it is expensive, only one dose is enough and it is effective in blocking the cytokine storm. We found that helmet CPAP and tocilizumab combination in COVID-19 lead severe ARDS could be promising to prevent intubation for patients.

Key words: Helmet CPAP; ARDS; COVID-19; Tocilizumab; Cytokine storm

Citation: Permana SA, Sugiarto A, Thamrin MH, Arifin, Harsini. A promising therapy of tocilizumab and helmet CPAP to prevent intubation for COVID-19 induced severe ARDS: a case report. Anaesth. pain intensive care 2020;24(6):659-663; DOI: 10.35975/apic.v24i6.1409

Received - 17 September 2020, Reviewed - 01 October 2020, Accepted - 6 November 2020

\section{Introduction}

We present a case of a severe ARDS due to COVID19 infection and a "cytokine-storm", which was diagnosed by the clinical signs; he had systemic inflammatory response syndrome (SIRS), and from the laboratory reports (high CRP). ${ }^{1}$ In ARDS, the $\mathrm{PaO}_{2}$ $/ \mathrm{FiO}_{2}$ ratio is deranged. From Berlin's criteria, we can classify ARDS. For the ARDS management we use flowchart from recent guidelines for management of ARDS in COVID-19, most of which prefer using non- invasive technique initially. One of the techniques is helmet CPAP. ${ }^{2-7}$

Helmet CPAP is a device delivering positive pressure without invasive methods and it is more comfortable than mask. It is stable, allow longer use and has less complications than the mask. ${ }^{4}$ To minimize complications such as $\mathrm{CO}_{2}$ entrapment and noise, we use a moderate flow of $45 \mathrm{l} / \mathrm{min}$ and use HME filter to create warm and humid air and to reduce noise. ${ }^{3,5}$ From a recent study published in Italy, a combination of helmet CPAP and prone position seems to be promising to prevent intubation in COVID-19 induced 
ARDS patient and become the first choice for ARDS induced by COVID-19 in Italy. ${ }^{4}{ }^{6}$ Helmet CPAP cannot decrease the work of breathing actively, but by recruiting the alveoli, it improves compliance, and normalizes the ventilation perfusion mismatch in ARDS induced by COVID-19., 7 The use of helmet CPAP has been proven to recruite non-aerated alveoli in dependent pulmonary regions, it also helps to stabilize the airways. Moreover, CT scan showed that helmet CPAP produces homogeneity of distribution in the lung volume. ${ }^{7}$

The use of tocilizumab has been recommended by a recent study, which included 250 patients with COVID-19 in four different countries, and showed that the use of tocilizumab can improve clinical condition and lower the mortality; even though the benefit was not statistically significant in some other studies. ${ }^{8-11}$ This therapy is safe and effective for COVID-19 patients even with mild and moderate renal insufficiency. ${ }^{8}, 11$ This drug improves clinical condition within 12 to 72 hours, which continues to improve over the next ten days. Tocilizumab work in blocking iL-6 receptor that can improve the "cytokinestorm" state. ${ }^{11}$ Some researchers have suggested to make this drug as a rescue therapy. ${ }^{9}, 10$

\section{Case report}

A 52 yrs old male, positive for covid-19 in rapid test, presented with fever, dyspnea and tachycardia. The patient had no history of dyspnea before the current illness. He was on treatment for diabetes mellitus and hypertension. He lived in an area which is endemic for COVID-19.

\subsection{Clinical features}

His clinical examination revealed body temperature $39.4^{\circ} \mathrm{C}$, respiratory rate $28-32 / \mathrm{min}$, pulse rate 129 bpm, and blood pressure 139/64 mmHg. On chest examination, we found ronchi in both sides of the chest. Laboratory findings showed leukocytosis $\left(11,890 / \mathrm{mm}^{3}\right)$, high blood sugar $(323 \mathrm{mg} / \mathrm{dl})$, high CRP (26 mg/l), low serum sodium (126 mmol/l), low chloride (91 mmol/l), high SGOT (355 u/l), high SGPT $(156 \mathrm{u} / \mathrm{l})$, and high procalcitonin $(4.19 \mathrm{ng} / \mathrm{ml})$. From the rapid test of antibodies IgM and IgG for COVID-19 was reactive. Other laboratory findings (hemoglobin, platelets, bilirubin, urea and creatinine)
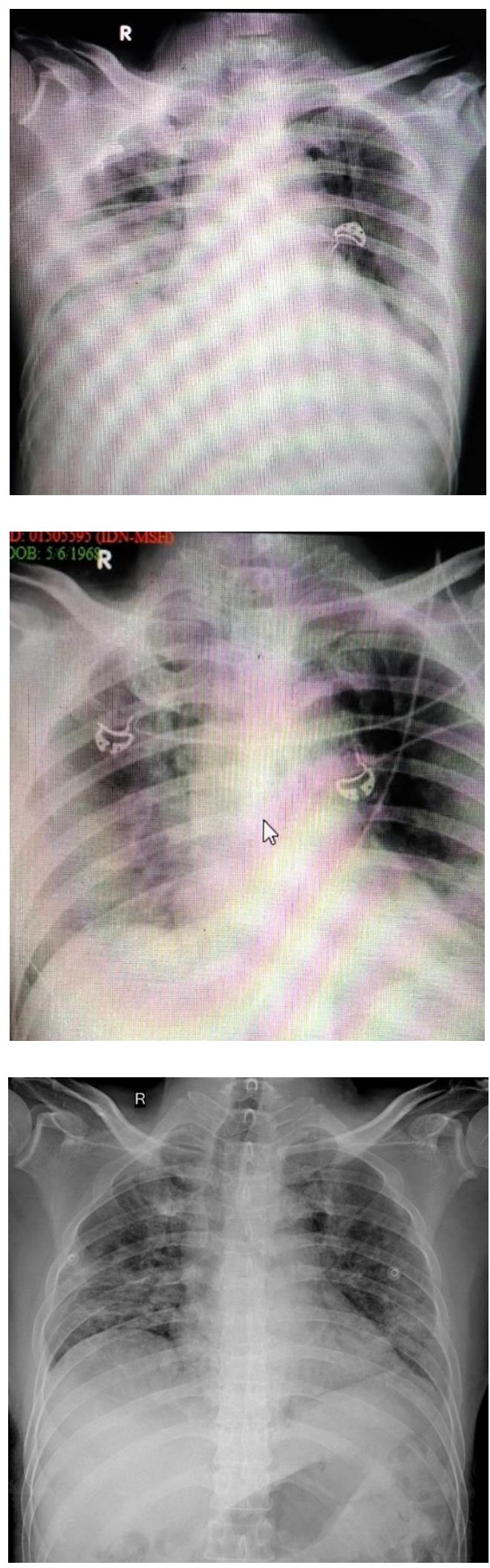

Figure 1(A, B, C): Chest $x$-ray showing gra dual improvement in lung structure 
were normal. His chest $\mathrm{x}$-ray showed signs of pneumonia suspected of COVID-19 (Figure 1). On day 3, his $\mathrm{SpO}_{2}$ fell low (88-92\%) with increase in supplemental $\mathrm{O}_{2}$, using non-rebreather mask (NRM) up to $12-151 / \mathrm{min}$, D-dimer level was $6922 \mathrm{ng} / \mathrm{ml}$. So he was transferred to ICU.

\subsection{Timeline}

Table 1: Vital signs and therapy

\begin{tabular}{|c|c|c|c|c|c|c|c|c|c|c|c|}
\hline \multirow{2}{*}{ Day } & \multirow{2}{*}{1} & \multirow{2}{*}{2} & \multicolumn{2}{|r|}{3} & \multirow{2}{*}{4} & \multirow{2}{*}{5} & \multirow{2}{*}{15} & \multirow{2}{*}{17} & \multirow{2}{*}{18} & \multirow{2}{*}{19} & \multirow{2}{*}{25} \\
\hline & & & pre & post & & & & & & & \\
\hline GCS & $\mathrm{CM}$ & $\mathrm{CM}$ & $\mathrm{CM}$ & $\mathrm{CM}$ & $\mathrm{CM}$ & $\mathrm{CM}$ & $\mathrm{CM}$ & $\mathrm{CM}$ & $\mathrm{CM}$ & $\mathrm{CM}$ & $\mathrm{CM}$ \\
\hline $\begin{array}{l}\mathrm{BP} \\
(\mathrm{mmHg})\end{array}$ & $\begin{array}{c}139 / \\
64\end{array}$ & $\begin{array}{c}124 / \\
82\end{array}$ & $\begin{array}{c}124 / \\
98\end{array}$ & $\begin{array}{c}110 / \\
96\end{array}$ & $\begin{array}{c}129 / \\
97\end{array}$ & $\begin{array}{c}155 / \\
109\end{array}$ & $\begin{array}{c}141 / \\
105\end{array}$ & $\begin{array}{c}141 / \\
105\end{array}$ & $\begin{array}{c}124 / \\
82\end{array}$ & $\begin{array}{c}155 / \\
109\end{array}$ & $\begin{array}{c}135 \text { / } \\
73\end{array}$ \\
\hline HR (bpm) & 129 & 118 & 112 & 77 & 89 & 93 & 89 & 88 & 88 & 87 & 87 \\
\hline $\mathrm{RR}(\mathrm{xpm})$ & 28 & 28 & 28 & 22 & 27 & 27 & 26 & 28 & 24 & 24 & 19 \\
\hline $\begin{array}{l}\operatorname{Temp}\left({ }^{\circ} \mathrm{C}\right. \\
\end{array}$ & 39.4 & 38.8 & 38.6 & 36.8 & 36.8 & 36.8 & 36.5 & 36.5 & 36.5 & 36.5 & 36.5 \\
\hline $\mathrm{SpO}_{2}(\%)$ & 96 & 92 & 88 & 100 & 95 & 95 & 99 & 100 & 100 & 100 & 97 \\
\hline \multirow[t]{2}{*}{ Therapy } & $\begin{array}{c}\mathrm{NR} \\
\mathrm{M} \\
8 \\
\mathrm{I} / \mathrm{min}\end{array}$ & $\begin{array}{c}\mathrm{NR} \\
\mathrm{M} \\
12 \\
\mathrm{I} / \mathrm{min}\end{array}$ & $\begin{array}{c}\mathrm{NR} \\
\mathrm{M} \\
12 \\
\mathrm{I} / \mathrm{min}\end{array}$ & $\begin{array}{l}\text { Helmet } \\
\text { CPAP }\end{array}$ & $\begin{array}{c}\mathrm{NR} \\
\mathrm{M} \\
7 \\
\mathrm{I} / \mathrm{min}\end{array}$ & $\begin{array}{l}\mathrm{NRM} \\
7 \mathrm{l} / \mathrm{min}\end{array}$ & $\begin{array}{c}\text { NRM } \\
7 \\
\text { I/min }\end{array}$ & $\begin{array}{l}\mathrm{NRM} \\
7 \mathrm{l} / \mathrm{min}\end{array}$ & $\begin{array}{c}\text { Nasal } \\
\text { cannul } \\
\text { a } \\
5 \mathrm{l} / \mathrm{min} \text {, } \\
\text { prone }\end{array}$ & $\begin{array}{c}\text { Nasal } \\
\text { cannul } \\
\text { a } 4-5 \\
\text { l/min }\end{array}$ & $\begin{array}{l}\text { Room } \\
\text { air }\end{array}$ \\
\hline & & & & $\begin{array}{c}\text { Tocilizuma } \\
\text { b }\end{array}$ & & $\begin{array}{c}\text { Convalescen } \\
\text { t plasma }\end{array}$ & $\begin{array}{c}\text { Swa } \\
\text { b } \\
\text { taken }\end{array}$ & $\begin{array}{c}\text { PCR } \\
\text { from } \\
\text { swab } \\
\text { day } 15 \\
\text { negativ } \\
\text { e }\end{array}$ & $\begin{array}{l}\text { Move } \\
\text { to ICU } \\
\text { non- } \\
\text { covid }\end{array}$ & $\begin{array}{l}\text { Move } \\
\text { to ward }\end{array}$ & $\begin{array}{l}\text { Discharg } \\
\text { e home }\end{array}$ \\
\hline
\end{tabular}

$N R M=$ non-rebreather mask, $C P A P=$ Continuous positive airway pressure

\subsection{Diagnostic Assessment}

This patient was diagnosed with severe COVID-19 from real time PCR, severe ARDS from blood gas analysis $\left(\mathrm{PaO}_{2} / \mathrm{FiO}_{2}\right.$ ratio 54), and co-infection with bacterial pneumonia (Klebsiella pneumoniae) from sputum culture. His co-morbid diseases were confirmed by laboratory test; diabetes mellitus from high blood sugar test; and hypertension and heart disease from blood pressure and chest x-rays (a cardiothoracic ratio $52 \%$ ).

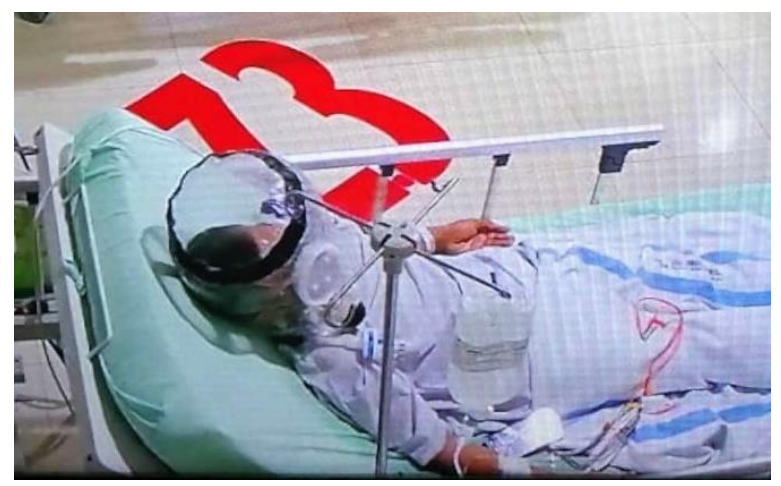

Figure 2: Patient with Helmet CPAP

\subsection{Therapeutic interventions}

The patient in ICU got helmet CPAP for oxygen supplementation. Then for the cytokine storm management, we used tocilizumab $400 \mathrm{mg}$ once combined with dexamethasone $5 \mathrm{mg}$ q8hr. The initial blood and sputum cultures were positive for Klebsiella infection, which was sensitive to piperacillin/tazobactam. We check the D-dimer level, and the result was high $(6922 \mathrm{ng} / \mathrm{ml})$, so we started prophylactic anticoagulant. Additional therapies for this patient included;

- Piperacillin/tazobactam $4.5 \mathrm{~g} \mathrm{q} 6 \mathrm{hr}$ for bacterial infection

- Azithromycin 500 mg q.i.d, as standard covid therapy

- $\quad \mathrm{N}$-acetylcysteine (NAC) $10 \% 6 \mathrm{ml}$ q.i.d, as mucolytic

- Vitamin C $2 \mathrm{~g} \mathrm{q} 8 \mathrm{hr}$ as standard covid therapy

- Insulin aspart $\left(\right.$ Novorapid $\left.^{\circledR}\right)$ 8-8-8 iu, Insulin glargine (Lantus ${ }^{\circledR}$ ) 0-0-0-10 iu for diabetes mellitus 
- Enoxaparine $40 \mathrm{mg} \mathrm{q} 12 \mathrm{hr}$, as a prophylactic anticoagulant

- Carvedilol $\left(\mathrm{Coreg}^{\circledR}\right) 3.25 \mathrm{mg}$ q.i.d., for rate control

- Dexamethasone $5 \mathrm{mg} \mathrm{q} 8 \mathrm{hr}$ for reducing cytokine storm

\subsection{Follow-up and Outcomes}

This patient was followed up daily, for vital signs and main symptoms. For laboratory testing we checked blood sugar twice a day. Other laboratory check-up was based upon clinical condition of the patient. To document the benefits of helmet CPAP plus other medication, repeated blood gas analysis and chest $\mathrm{x}$ rays were ordered.

\section{Discussion}

This patient was in severe ARDS when he was admitted to ICU, and after applying helmet CPAP the $\mathrm{SpO}_{2}$ increased to $100 \%$. From blood gas analysis his $\mathrm{PaO}_{2}$ was $167.8 \mathrm{mmHg}$, with $\mathrm{PaCO}_{2} 33.5 \mathrm{mmHg}$. The $\mathrm{PaCO}_{2}$ is higher when patient using helmet CPAP than when we decrease the $\mathrm{O}_{2}$ supplementation with NRM $71 /$ min. It may be because the RR was decreased when using helmet CPAP. This patient also suffered cytokine storm, which is indicated from the raised CRP and the sign of SIRS, so we administered tocilizumab $400 \mathrm{mg}$ within $90 \mathrm{~min}$. After that, the clinical condition gradually got better, the fever became normal, the HR and blood pressure decreased, and the patient felt more comfortable. The clinical signs showed better steady progress until the patient was discharged home.

Patient felt more comfortable after using helmet CPAP and receiving tocilizumab. The dyspnea got better, breathing became easier, and the fever got settled. After receiving the therapy, he could eat by himself, without the assistance by the nurse. And one day after combination therapy, he could read Quran by himself, he could speak again. Just the day before he had no strength to do it. We conclude that helmet CPAP can be considered in COVID patients with falling oxygen levels, along with high flow nasal oxygenation, BIPAP and conventional CPAP, before intubating the patients.

\section{Competing interests}

The authors have full access to all the data, take full responsibility for the accuracy of the data, and have authority over manuscript preparation and decisions to submit the manuscript for publication.

\section{Authors" contribution}

SAP: Concept, Conduct of study, Manuscript writing

AS, MHT: Conduct of study, Manuscript editing

A, H: Conduct of study, References

\section{References}

1. Zhu Z, Cai T, Fan L, Lou K, Hua X, Huang Z, et al. Clinical value of immune-inflammatory parameters to assess the severity of coronavirus disease 2019. Int J Infect Dis. 2020;95:332-9. [PubMed] DOI: 10.1016/j.ijid.2020.04.041

2. Hernández-Molina $R$, Fernández-Zacarías $F$, Benavente-Fernández I, Jiménez-Gómez G, LubiánLópez S. Effect of Filters on the Noise Generated by Continuous Positive Airway Pressure Delivered via a Helmet. Noise Health. 2017;19(86):20-3. [PubMed] DOI: $10.4103 / 1463-1741.199237$.

3. Ing RJ, Bills C, Merritt G, Ragusa R, Bremner RM, Bellia F. Role of Helmet-Delivered Noninvasive Pressure Support Ventilation in COVID-19 Patients. J Cardiothorac Vasc Anesth. 2020:S10530770(20)30419-5. [PubMed] DOI: 10.1053/j.jvca.2020.04.060

4. Longhini F, Bruni A, Garofalo E, Navalesi P, Grasselli $G$, Cosentini R, et al. Helmet continuous positive airway pressure and prone positioning: A proposal for an early management of COVID-19 patients. Pulmonology. 2020;26(4):186-91. [PubMed] DOI: 10.1016/j.pulmoe.2020.04.014

5. Lucchini A, Giani M, Isgrò S, Rona R, Foti G. The "helmet bundle" in COVID-19 patients undergoing non invasive ventilation. Intensive Crit Care Nurs. 2020;58:102859-. [PubMed] DOI: 10.1016/j.iccn.2020.102859

6. Privitera D, Angaroni L, Capsoni N, Forni E, Pierotti F, Vincenti $F$, et al. Flowchart for non-invasive ventilation support in COVID-19 patients from a northern Italy Emergency Department. Intern Emerg Med. 2020:1-5. [PubMed] DOI: $10.1007 / \mathrm{s} 11739-020-02370-8$

7. Radovanovic D, Rizzi M, Pini S, Saad M, Chiumello DA, Santus P. Helmet CPAP to Treat Acute Hypoxemic Respiratory Failure in Patients with COVID-19: A Management Strategy Proposal. Journal of clinical medicine. 2020;9(4). [PubMed] doi: 10.3390/jcm9041191

8. Campochiaro C, Della-Torre E, Cavalli G, De Luca G, Ripa $M$, Boffini $N$, et al. Efficacy and safety of 
tocilizumab in severe COVID-19 patients: a singlecentre retrospective cohort study. Eur J Intern Med. 2020;76:43-9. [PubMed]]

DOI: 10.1016/i.ejim.2020.05.021

9. Kewan T, Covut F, Al-Jaghbeer MJ, Rose L, Gopalakrishna KV, Akbik B. Tocilizumab for treatment of patients with severe COVID-19: A retrospective cohort study. EClinicalMedicine. 2020:100418. [PubMed] DOI: 10.1016/j.eclinm.2020.100418

10. Toniati P, Piva S, Cattalini M, Garrafa E, Regola F,
Castelli $F$, et al. Tocilizumab for the treatment of severe COVID-19 pneumonia with hyperinflammatory syndrome and acute respiratory failure: A single center study of 100 patients in Brescia, Italy. Autoimmunity reviews. 2020;19(7):102568. [PubMed] DOI: 10.1016/j.autrev.2020.102568

11. Zhang S, Li L, Shen A, Chen Y, Qi Z. Rational Use of Tocilizumab in the Treatment of Novel Coronavirus Pneumonia. Clin Drug Investig. 2020;40(6):511-8. [PubMed] DOI: $10.1007 /$ s40261-020-00917-3 